\title{
PARAMETRIC STUDY ON THE OVER STRENGTH CAPACITY OF BRIDGE PIERS UNDER EARTHQUAKES
}

\author{
Ammar A. Abdul Rahman ${ }^{1}$ and Ahmed Mohammed Abdullah ${ }^{2}$
}

\begin{abstract}
In the seismic analysis of reinforced concrete bridge piers, there is now a common awareness that excessive strength of the concrete is essential and required in the analysis up to failure of the pier. This means it is necessary to assess the overstrength capacity of pier columns subjected to earthquake after incorporating the concrete plastic damage parameter in the analysis. A three dimensional finite element model of the complete typical pier used in Iraqi bridges was developed using the computer software ABAQUS where concrete plasticity damage was incorporated. The model was used in studying the behavior of typical bridge piers used in Iraq up to failure under the action of actual earthquake took place and recorded in Iraq. The model didn't fail due to reaching the concrete compressive strength at certain locations but rather continued following the formation of plastic hinges at the critical sections and making use of the overstrength capacity of the concrete due to its plastic damage strength. It was observed that such piers can sustain the actual earthquake took place and used only $17 \%$ of the concrete compressive damage capacity. To cover more cases, a parametric study was conducted where different columns' diameters were studied with multiples of the original earthquake intensity. From the study it was observed that the $800 \mathrm{~mm}$ diameter columns used with typical piers can sustain the original earthquake but with using only $41 \%$ of the concrete plastic damage capacity. This column was unable to carry out 2.5 and 3 times of the original earthquake and it will be recommended for designers not to use this column diameter in bridge piers in zones with earthquake activity. Piers with $1200 \mathrm{~mm}$ diameter columns can sustain larger earthquake intensities but the tensile cracks will spread at the outer faces of the columns which will reduce its compressive overstrength capacity. Following the formation of plastic hinges in the compression zones of concrete under the effect of earthquake loading up to failure after reaching a mechanism gave clear picture on the true capacity of the typical piers used in Iraq under the action of earthquakes. The piers can sustain 8 times of their capacities measured using their maximum compressive strengths. There will be cracks, and plastic hinges but the pier will not fail until the structure reaches a mechanism of collapse.
\end{abstract}

Keywords - Bridge piers, earthquakes, overstrength capacity of concrete, 3D FEA, ABAQUS.

\section{INTRODUCTION}

The aim of this work to investigate how much overstrength can the reinforced concrete typical piers of the bridges in Iraq made of circular columns sustain earthquake loading even after the formation of the plastic hinges in the piers. Actual earthquake data took place in Iraq will be imposed over a typical pier of simply supported bridges in Iraq and the response will be traced after the formation of first plastic hinges till the complete failure of the pier due to mechanism. Parametric study covering different earthquake intensities and pier columns' diameters used in Iraq will be investigated to reach what final limits of strength capacities of these piers, can sustain.

\section{Proposed Algorithm}

A. Finite Element Formulation

${ }^{1}$ Faculty Member - Department of Civil Engineering AL-Nahrain University, Baghdad, Iraq

${ }^{2}$ Department of Civil Engineering AL-Nahrain University, Baghdad, Iraq 
In this study, the numerical simulations to investigate the structural behavior of bridge piers under earthquake loading and their failure mode have been performed by the FE-code ABAQUS/CAE version 6.13. The concrete damaged plasticity (CDP) material model has been used to define the cyclic behavior of concrete and reinforcement respectively.

\section{B Geometric Model}

The finite element analysis included modeling of a typical bridge pier of typical simply supported bridges in Iraq. Most of Iraqi bridges are made of simply supported spans of $24 \mathrm{~m}$ with $12 \mathrm{~m}$ deck width to allow two lanes of traffic each side. The deck is made of reinforced concrete slab with eight precast prestressed (pretensioned) concrete girders. Piers are made of three circular columns of $1 \mathrm{~m}$ diameter and across beam with a width of $2 \mathrm{~m}$ to give enough space to locate two sets of girders for each span. Typical details and dimensions are shown in Fig. 1. Reinforcement details of the columns and cross head are shown in Table -1 and -2. The finite element model of the typical piers is shown in Fig. 2.

Table 1 Details of Columns of Typical Pier

\begin{tabular}{|l|l|l|l|l|}
\hline & $\begin{array}{l}\text { Diameter } \\
(\mathrm{m})\end{array}$ & $\begin{array}{l}\text { Length } \\
(\mathrm{m})\end{array}$ & $\begin{array}{l}\text { Longitudinal } \\
\text { Reinforcement }\end{array}$ & Stirrups \\
\hline Column & 1 & 5.5 & $32 \varphi 25$ & $\varphi 12 / 150$ pitch \\
\hline
\end{tabular}

Table 2 Details of Cross head

\begin{tabular}{|l|l|l|l|l|l|l|}
\hline & $\begin{array}{l}\text { Length } \\
(\mathbf{m})\end{array}$ & $\begin{array}{l}\text { Width } \\
(\mathbf{m})\end{array}$ & $\begin{array}{l}\text { Depth } \\
(\mathbf{m})\end{array}$ & $\begin{array}{l}\text { Bottom } \\
\text { Reinforcement }\end{array}$ & $\begin{array}{l}\text { Top } \\
\text { Reinforcement }\end{array}$ & Stirrups \\
\hline Cross Head & $\mathbf{1 2}$ & $\mathbf{2}$ & $\mathbf{1 . 6}$ & $\mathbf{9 \varphi 2 5}$ & $\mathbf{1 2 \varphi 2 5}$ & $\varphi 16 / 150$ \\
\hline
\end{tabular}

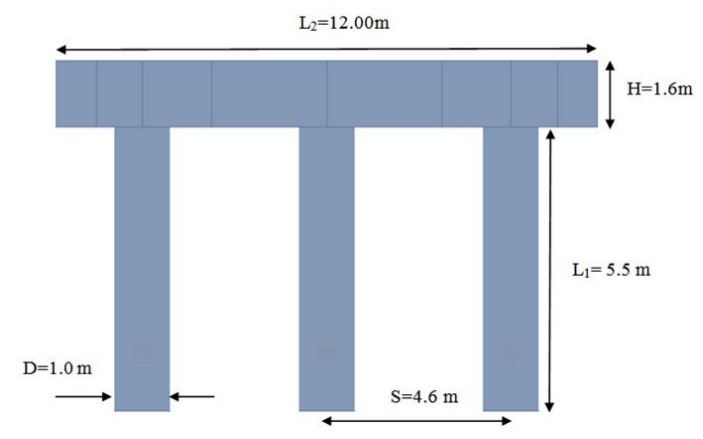

Figure 1. Dimensions of typical pier under investigation

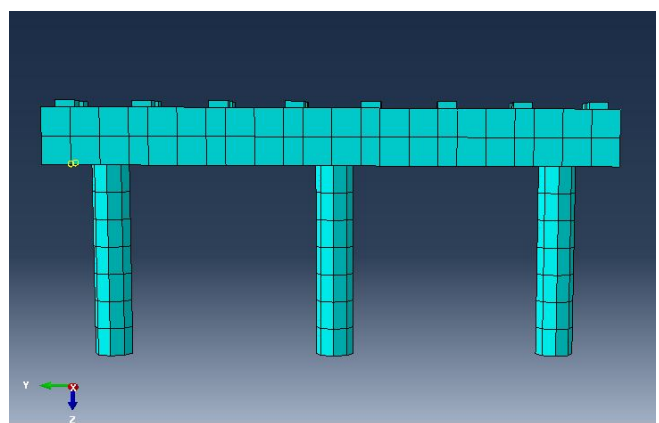

Figure 2. Finite element model of the typical pier under investigation

\section{MATERIAL INPUT DATA}




\section{A Concrete}

The nonlinear behavior of concrete is considered for analysis. In this study, plastic behavior of materials was defined and damage plasticity model for concrete was used, including the damaged part. All parameters are derived from the mean strength of the concrete $\mathrm{F}_{\mathrm{cm}}$. Young's Modulus, density and Poisson's ratio of concrete are based on recommended values in $\mathrm{MC10}$ [2].

1. Concrete Compression Data

Compression data was obtained from [2] a concrete damaged plasticity identification study using structural concrete with compressive strength $50 \mathrm{MPa}$. The defined compression stress/strain curve and the corresponding damage curve are presented in Table -3 and Figures 3 and 4.

Table 3 Concrete Compressive strength data

\begin{tabular}{|l|l|l|}
\hline Stress $[\mathrm{MPa}]$ & Damage C $[-]$ & Crushing Strain $[-]$ \\
\hline $\mathbf{1 5 . 0 0 0 0 0 0}$ & $\mathbf{0}$ & $\mathbf{0}$ \\
\hline $\mathbf{2 0 . 1 9 7 8 0 4}$ & $\mathbf{0}$ & $\mathbf{0 . 0 0 0 0 7 4 7 3 0 7}$ \\
\hline $\mathbf{3 0 . 0 0 0 6 0 9}$ & $\mathbf{0}$ & $\mathbf{0 . 0 0 0 0 9 8 8 4 7 9}$ \\
\hline $\mathbf{4 0 . 3 0 3 7 8 1}$ & $\mathbf{0}$ & $\mathbf{0 . 0 0 0 1 5 4 1 2 3 0}$ \\
\hline $\mathbf{5 0 . 0 0 7 6 9 2}$ & $\mathbf{0}$ & $\mathbf{0 . 0 0 0 7 6 1 5 3 8 0}$ \\
\hline $\mathbf{4 0 . 2 3 6 0 9 0}$ & $\mathbf{0 . 1 9 5 4 0 2}$ & $\mathbf{0 . 0 0 2 5 5 7 5 5 9 0}$ \\
\hline $\mathbf{2 0 . 2 3 6 0 9 0}$ & $\mathbf{0 . 5 9 6 3 8 2}$ & $\mathbf{0 . 0 0 5 6 7 5 4 3 1 0}$ \\
\hline $\mathbf{5 . 2 5 7 5 5 7}$ & $\mathbf{0 . 8 9 4 8 6 5}$ & $\mathbf{0 . 0 1 1 7 3 3 1 1 9 0}$ \\
\hline
\end{tabular}

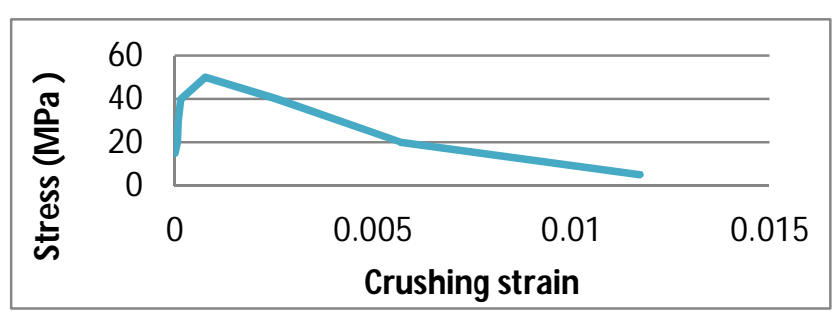

Figure 3. Concrete Compression stress- crushing strain relation

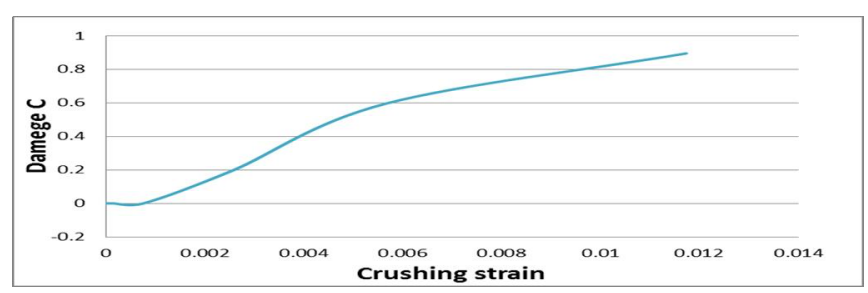

Figure 4. Concrete Compression Damage adopted

\section{Concrete Tension Data}

Concrete tension data also obtained from [2]. The defined tensile stress /cracking strain curve and corresponding damage curve are presented in Table 4 and Figures 5 and 6.

Table 4 Concrete Tension Stiffening data

\begin{tabular}{|l|l|l|}
\hline Stress $[\mathrm{MPa}]$ & DamageT $[+]$ & Cracking Strain $[+]$ \\
\hline $\mathbf{1 . 9 9 8 9 3 0}$ & $\mathbf{0}$ & $\mathbf{0}$ \\
\hline $\mathbf{2 . 8 4 2 0 0 0}$ & $\mathbf{0}$ & $\mathbf{0 . 0 0 0 0 3 3 3 3 0}$ \\
\hline $\mathbf{1 . 8 6 9 8 1 0}$ & $\mathbf{0 . 4 0 6 4 1 1}$ & $\mathbf{0 . 0 0 0 1 6 0 4 2 7}$ \\
\hline
\end{tabular}




\begin{tabular}{|l|l|l|}
\hline $\mathbf{0 . 8 6 2 7 2 3}$ & $\mathbf{0 . 6 9 6 3 8 0}$ & $\mathbf{0 . 0 0 0 2 7 9 7 6 3}$ \\
\hline $\mathbf{0 . 2 2 6 2 5 4}$ & $\mathbf{0 . 9 2 0 3 8 9}$ & $\mathbf{0 . 0 0 0 6 8 4 5 9 3}$ \\
\hline $\mathbf{0 . 0 5 6 5 7 6}$ & $\mathbf{0 . 9 8 0 0 9 3}$ & $\mathbf{0 . 0 0 1 0 8 6 7 3 0}$ \\
\hline
\end{tabular}

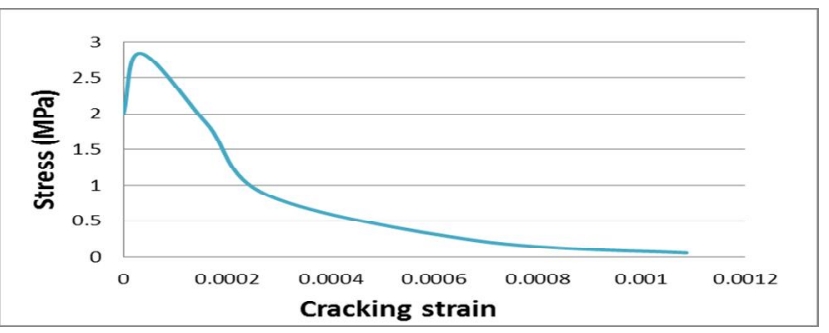

Figure 5. Concrete Tension stress - cracking strain relation adopted

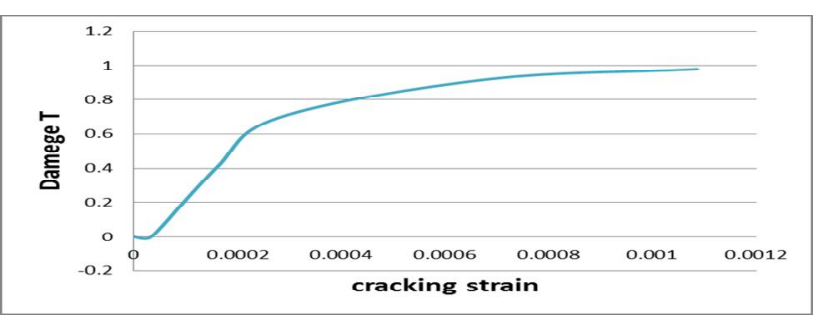

Figure 6. Concrete Tension Damage adopted

\section{B Reinforcing Steel}

For ASTM grade 60 reinforcing steel with fy= $414 \mathrm{MPa}$ the general plasticity relation was used to define plastic strain. Since steel is a much more homogeneous material, relative to concrete, a typical stress/strain curve was used to define steel plasticity as summarized in Figure 7.

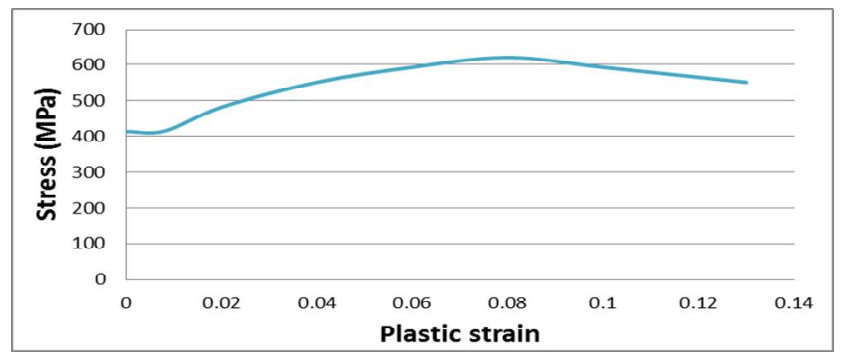

Figure 7 Steel Plastic Strain adopted

C Boundary Conditions and Load Cases

The point of connection between the columns and the piles cap are considered completely fixed. This was insured through using fixity for all nodes of column bases in all directions. The interactions between concrete and steel reinforcement as the embedded region and the concrete as the host element.

The loading applied to the bridge pier were:

1- Supper structure dead load and super imposed dead load.

2- Traffic live load according to Iraqi specification for loading of bridges (1978) and BS 5400.

3- Pier dead load

4- Earthquake loading applied horizontally along the cross head beam length (along y axis).

Figure 8 and 9 shows the loadings location and boundary condition, superstructure dead and live loads were marked with orange arrows. Earthquake load with yellow arrows at one side of the cross-head beam, and dead load of bridges piers was included in the analysis. 
From previous analyses for typical bridges in Iraq, loadings item (1) and (2) will result in a load of $2870 \mathrm{KN} / \mathrm{pad}$ (16 pads over the cross head). Loading item 3 will be calculated by the software. Loading item 4 will be of Ali-Al Gharbee earthquake was used as shown in Figures 10.

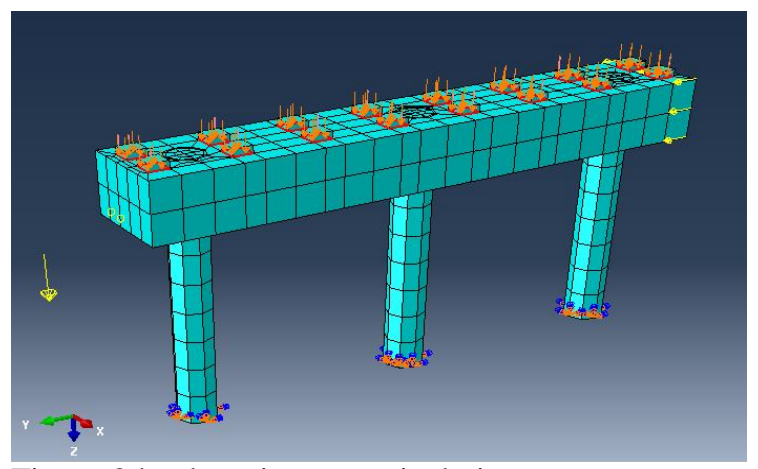

Figure 8 loads acting on typical pier

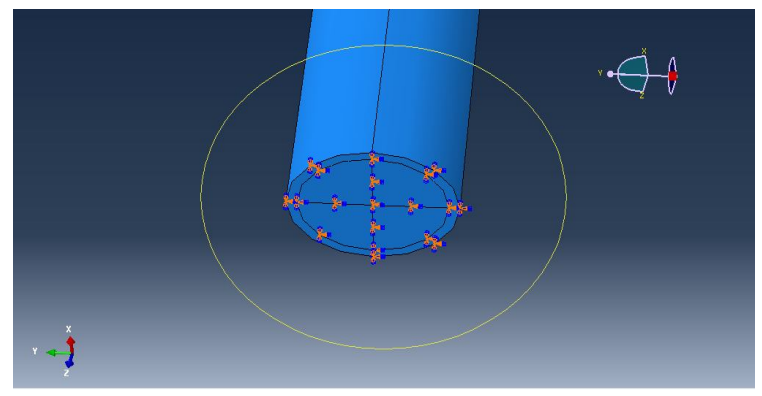

Figure 9 Boundary condition on the base of columns (complete fixity)

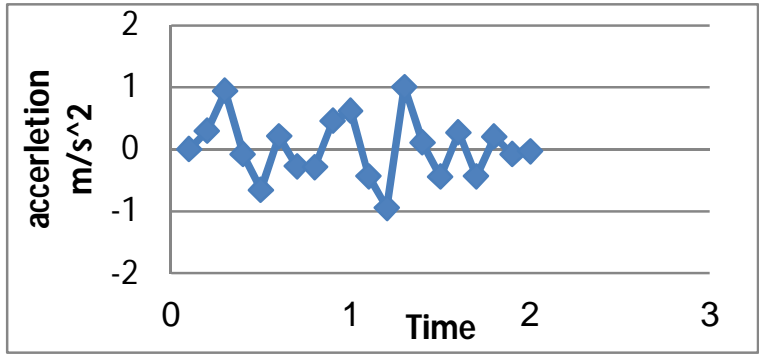

Figure 10 Ali Al Gharbee earthquake intensity used in present work

D Elements' Types

Bridge piers are modeled using three-dimensional finite element. In ABAQUS [Abaqus manual 6.13][1] the standard 3D stress elements can be used to model the concrete. Quadratic brick elements are chosen to provide higher precision for elements with strong distortions. These types of element capture stress concentrating better, and they are effective in bending and shear problems. It is worth mentioning that the integration with quadratic order elements is favorite as they yield accurate results. Therefore, the C3D8R (An 8-node quadratic brick element with full integration) shown in Fig. 11 are chosen to model the concrete. Truss elements are used for reinforcing bars because they don't supply a very high bending stiffness. Perfect bond is assumed to occur between concrete and steel bars throughout the entire analysis. Therefore, the T3D2 (A 2-node linear 3-D truss element) is used to model the reinforcing bars. 

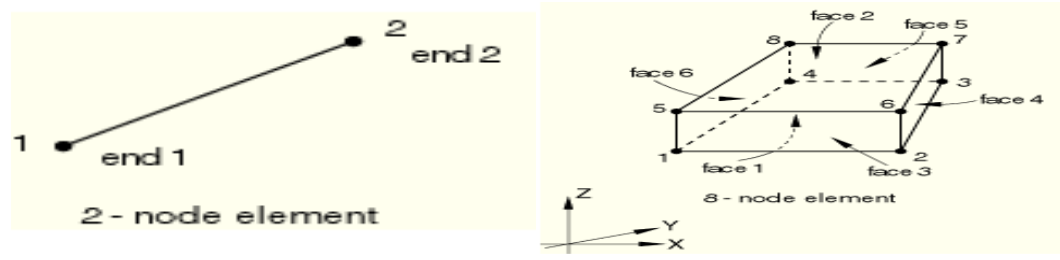

T3D2 ( 2- node linear 3D truss) Element

C3D8R (8-node Solid 3D Element)

Figure 11 Finite Element Type used for Modeling

E Three-Dimensional Finite Element Meshes

The three dimensional (3D) finite element meshes for concrete as shown in Fig. 12 and reinforcing bars as shown in Fig. 13 were completed and prepared for the earthquake analysis.

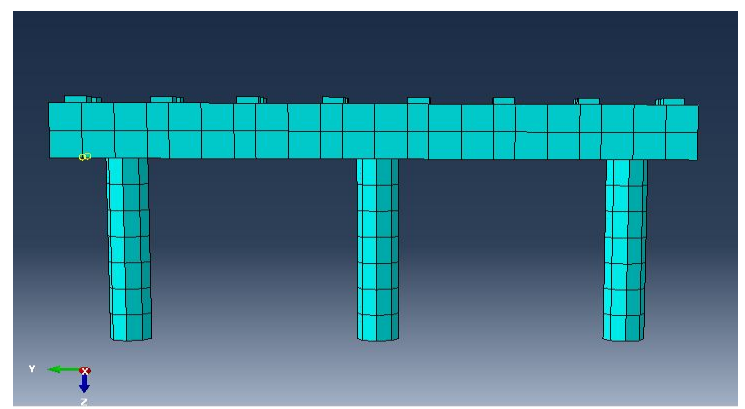

Figure 12 Mesh of concrete part of the pier

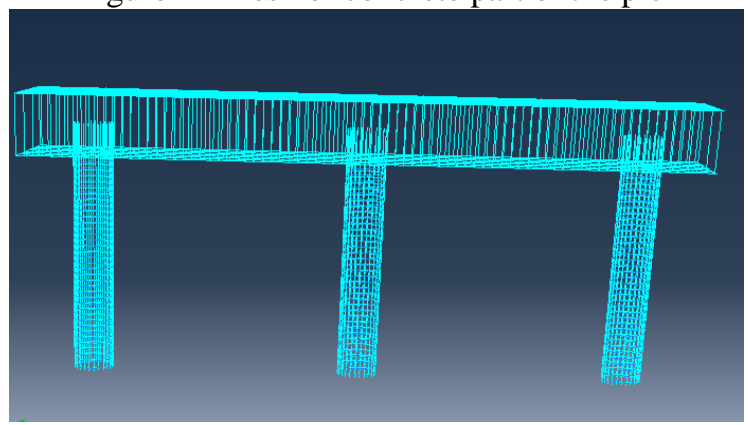

Figure 13 Mesh of reinforcing steel of the pier

\section{CASE STUDY RESULTS AND PARAMETRIC STUDY}

A Case Study Results

The typical pier under investigation was analyzed under the action of Ali Al Gharbee earthquake happened in Maysan province south of Iraq in 20 April 2013 with magnitude $\mathrm{Mw}=$ (4.9) with peak ground acceleration of $104.151 \mathrm{~cm} / \mathrm{sec}^{2}$. After applying the earthquake with all other acting loads on the pier it was found that no plastic damage was reached at any location on the three columns and the cross head up to the end of the earthquake excitation except $17 \%$ of concrete compression plastic damage parameter was recorded at the top part of the middle column as shown in Figure 14. The whole pier undergoes deformations but not exceeding the normal limits to reach the plastic regions of the concrete in compression. Figure 15 shows the plastic strain values reached in the three columns of the pier. Maximum strain was reached in column 2 (the middle column) with value of 0.002108 at end of earthquake response time. Figure 16 shows the displacements response of the whole pier at the end of earthquake excitation. Maximum deflection recorded was $49 \mathrm{~mm}$ at the cross head level. The tension cracking parameter shown in Figure 17 shows that under the action of static loads made of superstructure dead load and traffic live loads several locations reached the cracking level of deformation. As for the reinforcement of the cross head and the columns, Figure 18 gives the limits at the end of the earthquake of the longitudinal stresses in the main reinforcement of the pier. 
From the results of the earthquake analysis, it can be concluded that typical bridge piers can sustain Ali Al Gharbee earthquake without severe damage in the pier columns. No collapse will take place since the structure indeterminacy was not affected even if a complete plastic hinge was formed at the top of the middle column while only part of it within $17 \%$ passing the limits of the plastic damage took place at that spot. Further investigation on the pier with other earthquake intensities is required to know exactly how much the columns of the typical pier can sustain from the earthquake loading before the full failure of the structure takes place through the formation of several plastic hinges necessary to make a mechanism.

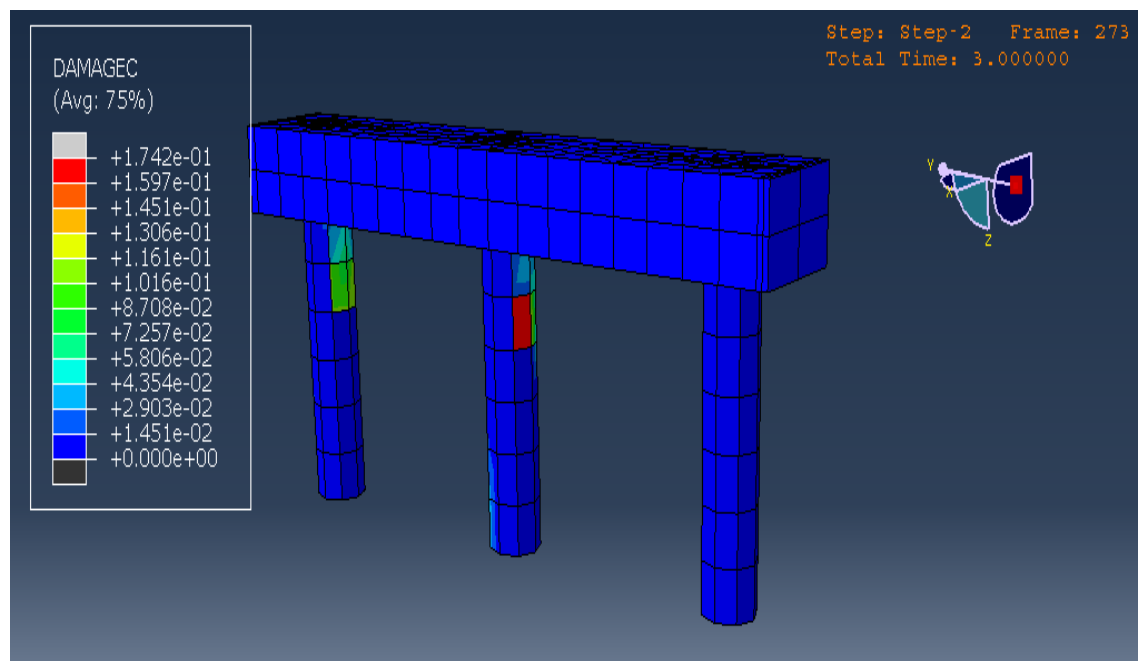

Figure 14 Compression Damage Zones of bridge pier with 1000 mm diameter Columns under Ali AL Gharbee earthquake

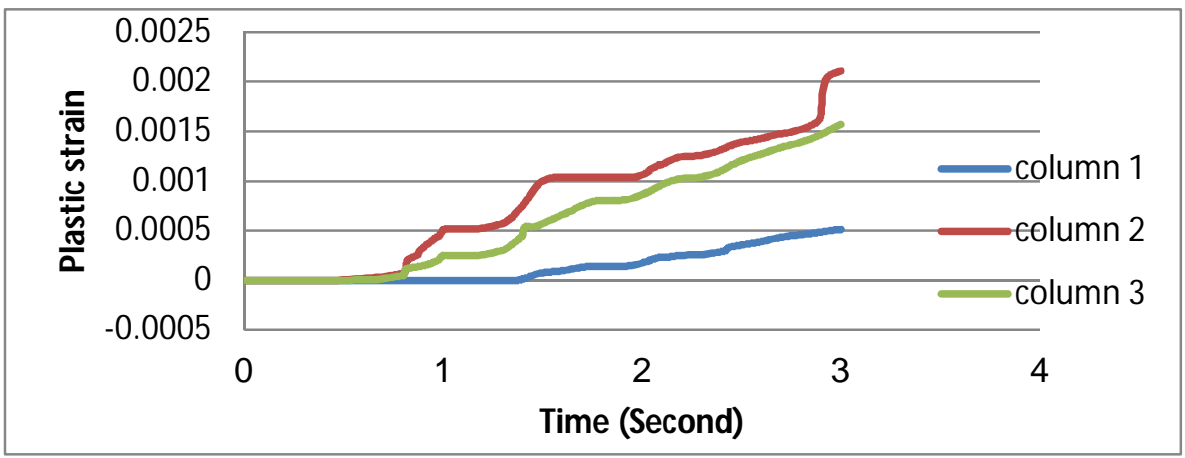

Figure 15 Plastic Strain of bridge piers with $1000 \mathrm{~mm}$ diameter Columns under Ali AL Gharbee earthquake 


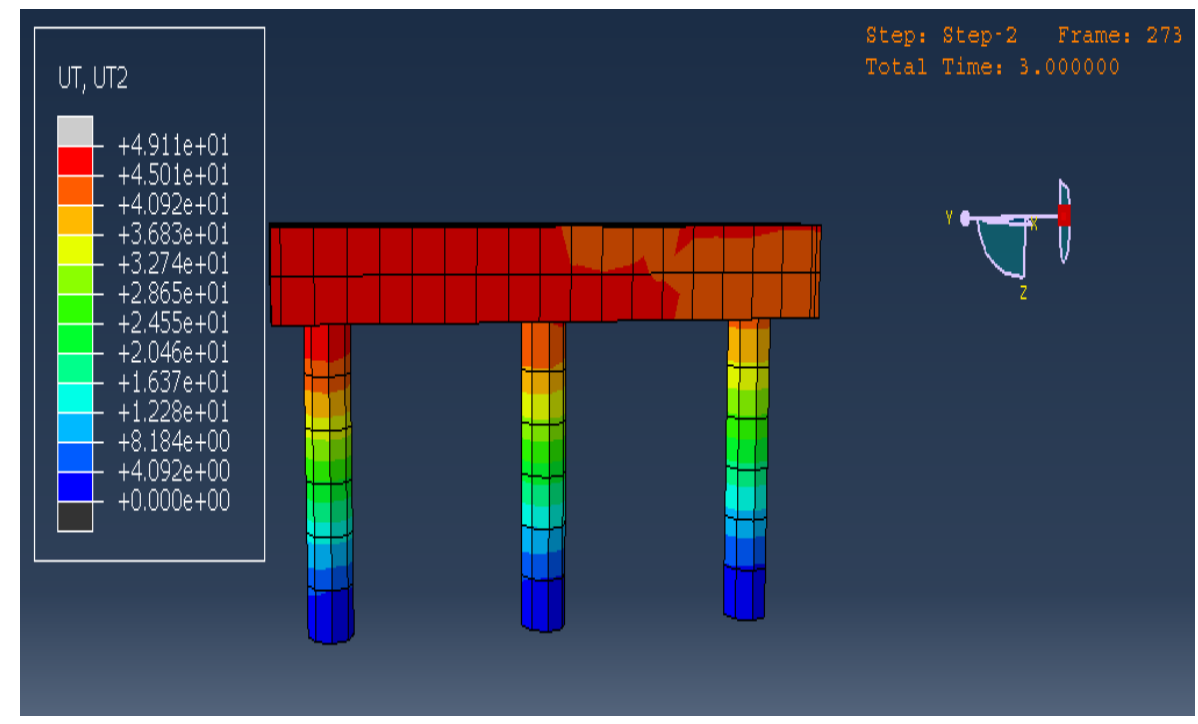

Figure 16 Horizontal displacement of Pier at end of Earthquake Excitation

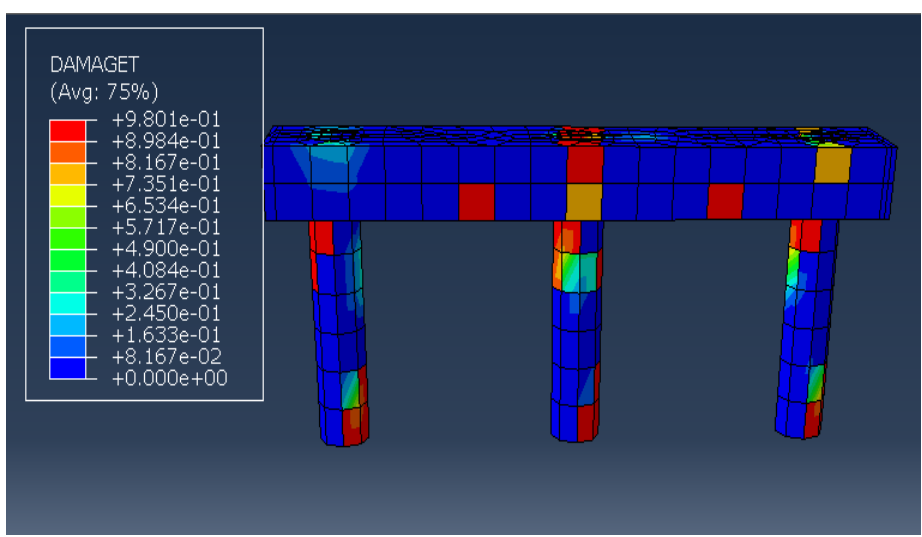

Figure17. Tension Cracking Location of Bridge Piers with $1000 \mathrm{~mm}$ diameter columns under Ali AL Gharbee Earthquake

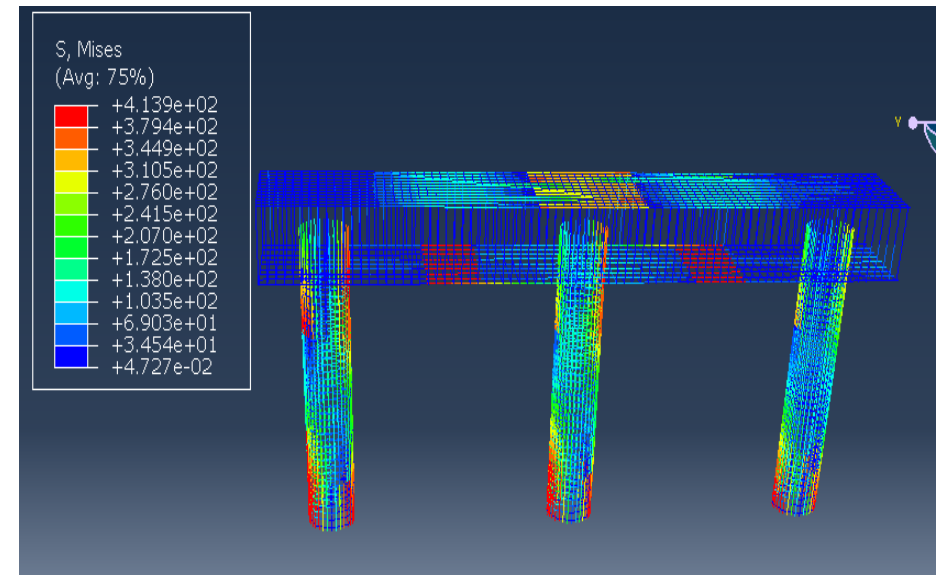

Figure 18 Maximum Longitudinal Tensile Stresses in Reinforcement of Bridge Piers with $1000 \mathrm{~mm}$ diameter columns under Ali AL Gharbee Earthquake 


\section{B Parametric Study}

From the general practice of reinforced concrete bridges in Iraq, the columns of the piers usually used are with diameters $800 \mathrm{~mm}, 1000 \mathrm{~mm}$ and $1200 \mathrm{~mm}$. Piers with these columns diameters will be subjected to multiples of the original Ali Al Gharbee earthquake ground-motion, namely 1.5, 2, 2.5 and 3 multiples. An earthquake of 3 times of Ali Al Gharbee earthquake is very high and much exaggerated but it is necessary to investigate the last stage of deformation taking place at the plastic hinges locations.

Each case will be analyzed up to the end of the earthquake excitation. The sequence of plastic hinges formation for each case will be traced. First plastic hinge formation will be marked through a figure showing the time at which the first plastic hinge was formed. Then other plastic hinges will be formed at the top or bottom ends of the columns. Results of plastic strain and plastic damage parameter (compression and tension) were calculated and drawn.

\section{Pier with 1000 mm Diameter Columns}

This pier was subjected to 1, 1.5, 2, 2.5, and 3 multiples of the original Ali Al Gharbee earthquake. Results of the compression damage parameter of the middle column (Column 2) and edge column at far side (Column 3 ) through the full earthquake duration ( 2 seconds) are shown in Fig. 19 and 20. Plastic strain accumulated with time on the three columns under two times of earthquake intensity are shown in Fig. 21. Plastic hinges formation with time under two times of original earthquake excitation is shown in Fig. 22. Tension cracking distribution and locations are shown in Fig. 23. From the full analysis of bridge pier with columns diameter of $1000 \mathrm{~mm}$ each, the over strength capacity ratio of the pier under different earthquake excitations made of multiples of the original Ali Al Gharbee earthquake is given in Table. The values show clearly that the pier with 1000 mm diameter columns can sustain not only the original Ali Al Gharbee earthquake excitation but three times of its magnitude where several plastic hinges will form but the pier will not fail and collapse due to the overstrength capacity it has due to its indeterminacy, rigidity and concrete compressive damage capability where it reached a maximum value of two third of its full compression strength at the end of the earthquake excitation.

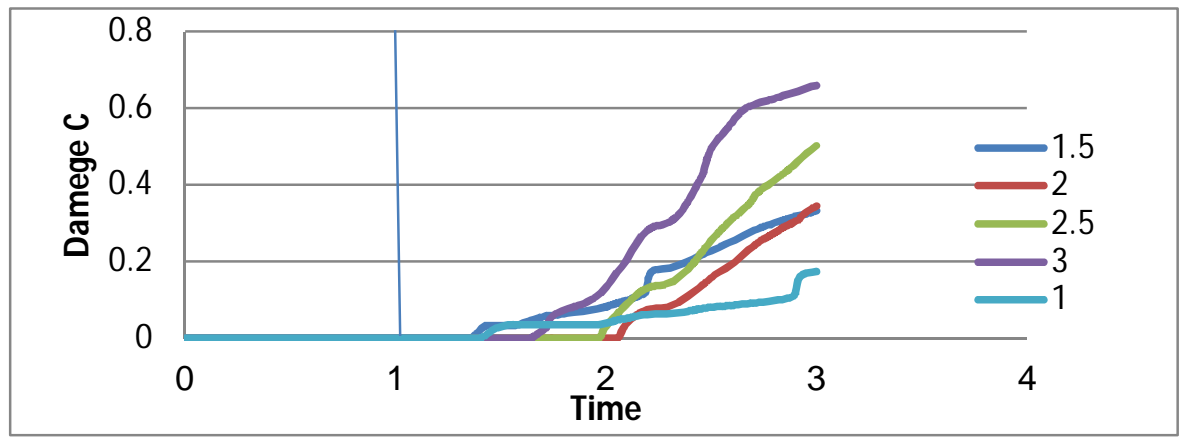

Figure 19 Compression Damage Parameter for middle column of 1000 mm diameter during ( 1, 1.5, 2, 2.5 and 3) of applied Earthquake Intensity

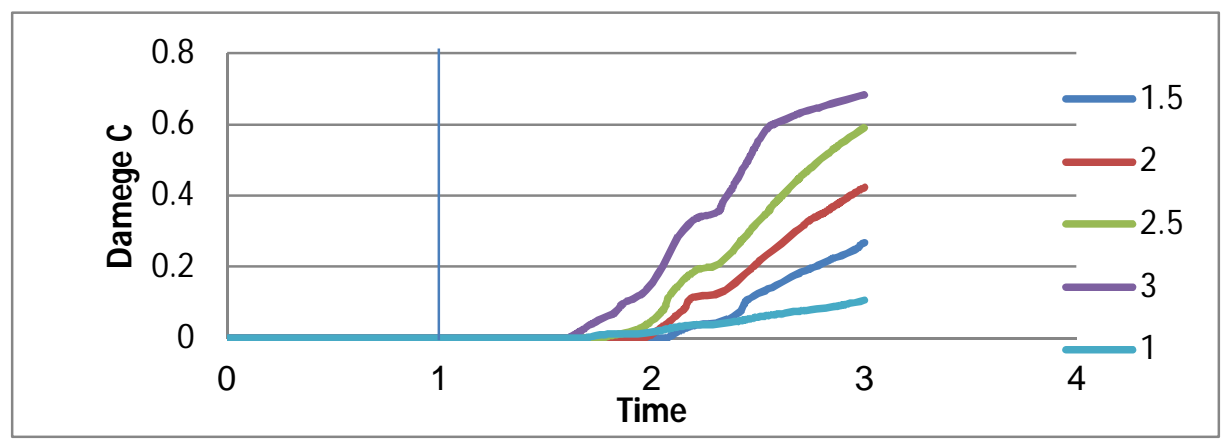

Figure 20 Compression Damage Parameter for edge column of 1000 mm diameter during ( 1, 1.5, 2, 2.5 and 3) of applied Earthquake Intensity 


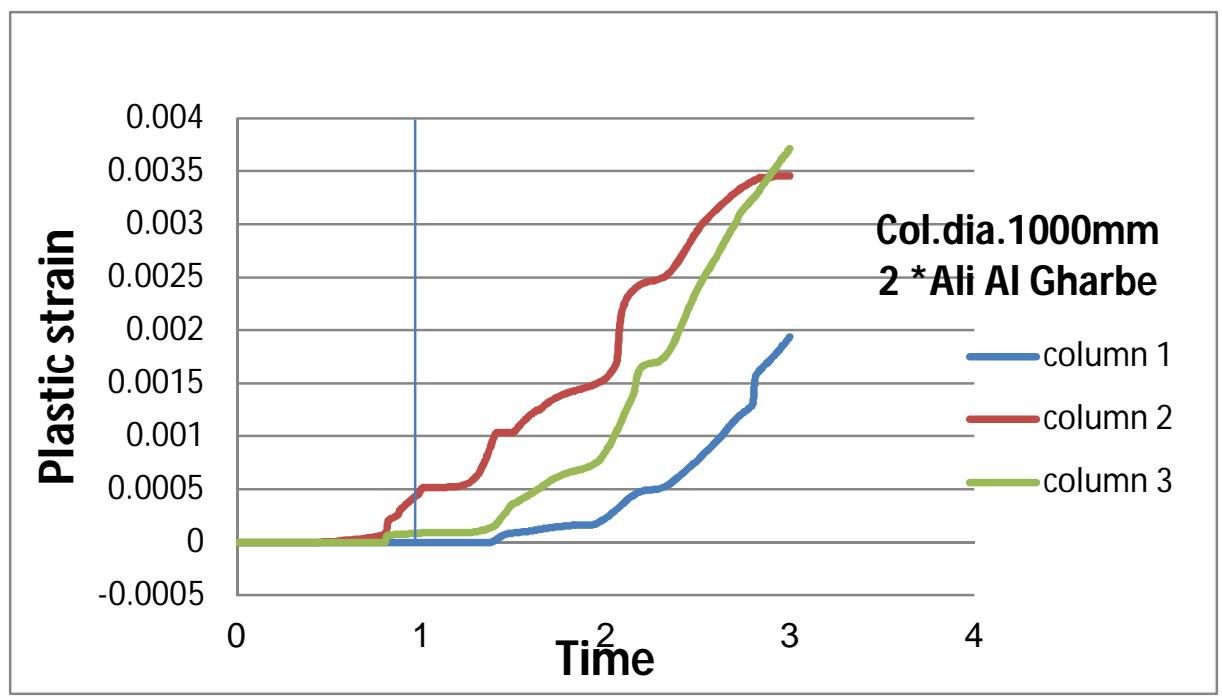

Figure 21. Plastic Strain of Pier with 1000 mm Columns Diameter under two times of Applied Earthquake Intensity

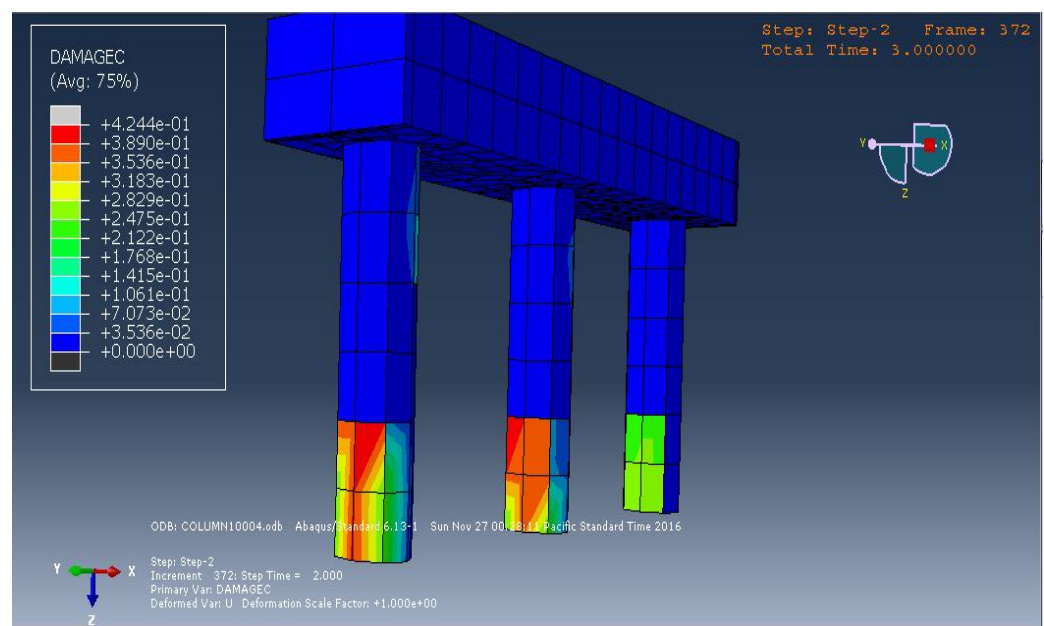

Figure 22. Compression damage location of Bridge Piers with $1000 \mathrm{~mm}$ under two times of Applied Earthquake Intensity 


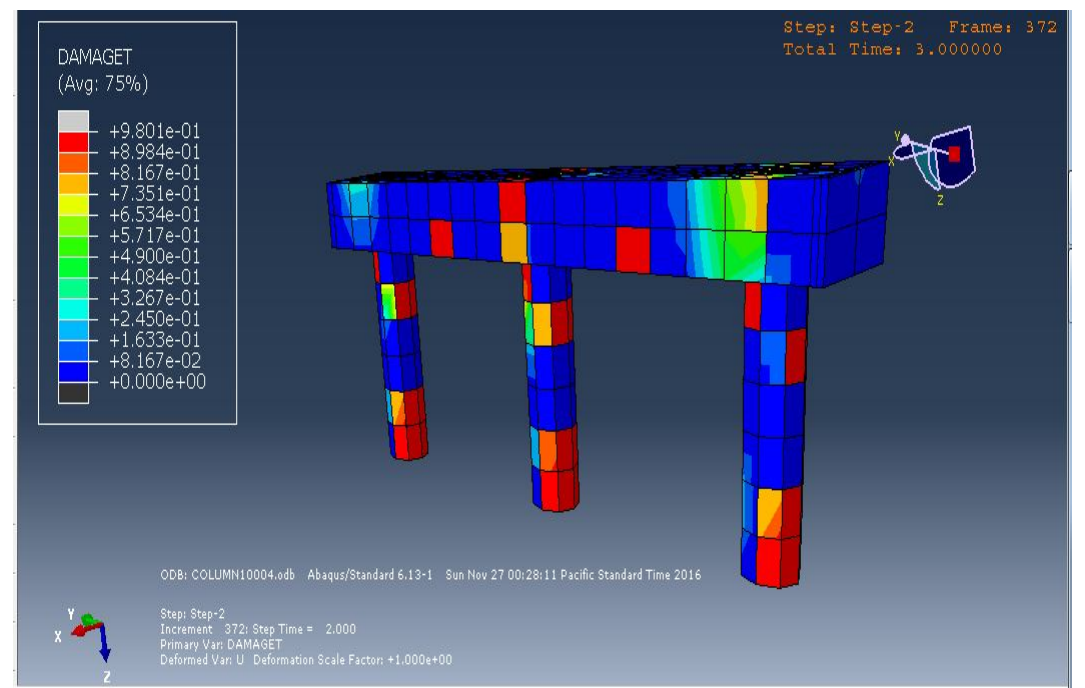

Figure 23. Tension Cracking Location of Bridge Piers with $1000 \mathrm{~mm}$ diameter under two times of Applied Earthquake Intensity

Table 6 OverStrength Capacity Ratio for Bridge Pier with 1000 mm diameter columns under different Earthquake Excitations

\begin{tabular}{|l|l|l|l|l|l|}
\hline & $\begin{array}{l}\mathbf{1}^{*} \text { Earthquake } \\
\text { Intensity }\end{array}$ & $\begin{array}{l}\mathbf{1 . 5 *} \text { Earthquake } \\
\text { Intensity }\end{array}$ & $\begin{array}{l}\mathbf{2}^{*} \text { Earthquake } \\
\text { Intensity }\end{array}$ & $\begin{array}{l}\mathbf{2 . 5}^{*} \text { Earthquake } \\
\text { Intensity }\end{array}$ & $\begin{array}{l}\mathbf{3}^{*} \text { Earthquake } \\
\text { Intensity }\end{array}$ \\
\hline $\begin{array}{l}\text { Middle } \\
\text { Column } \\
\text { (Column 2) }\end{array}$ & 0.17 & 0.332 & 0.34 & 0.5 & 0.66 \\
\hline $\begin{array}{l}\text { Edge Column } \\
\text { (Column 3) }\end{array}$ & 0.106 & 0.26 & 0.423 & 0.589 & 0.683 \\
\hline
\end{tabular}

\section{Pier with 800 mm Diameter Columns}

This pier was subjected to 1, 1.5, 2, 2.5, and 3 multiples of the original Ali Al Gharbee earthquake. Results of the compression damage parameter of the middle column (Column 2) and edge column at far side (Column 3) through the full earthquake duration ( 2 seconds) are shown in Fig. 24 and 25. Plastic strain accumulated with time on the three columns under 1.5 times of earthquake intensity are shown in Fig. 26. Plastic hinges formation with time under 1.5 times of original earthquake excitation is shown in Fig. 27. Tension cracking distribution and locations are shown in Fig. 28. From the full analysis of bridge pier with columns diameter of $800 \mathrm{~mm}$ each, the values show that the pier can sustain the original Ali Al Gharbee earthquake excitation, its 1.5 and 2 multiples but it cannot sustain 2.5 and three times of its magnitude where compressive plastic parameter passes over the $80 \%$ ratio and the plastic hinges will form and the pier will fail and collapse with these ratios of concrete compressive damage and the hinges became without any strength and the pier cannot stand such earthquake excitations. Displacements started to increase without any excitations leading to a pure mechanism case.

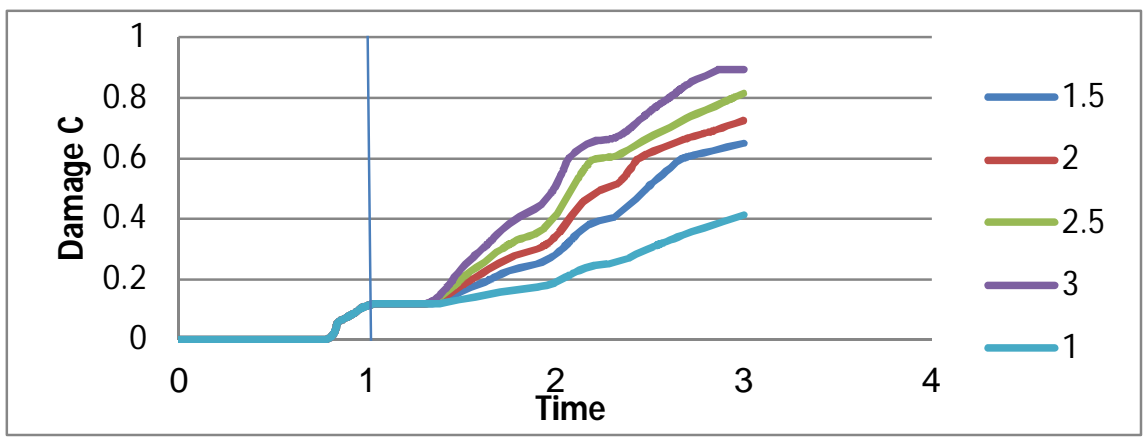


Figure 24. Compression Damage Parameter for Middle Column in Bridge pier with $800 \mathrm{~mm}$ diameter during (1, 1.5, 2, 2.5 and 3) of applied Earthquake Intensity

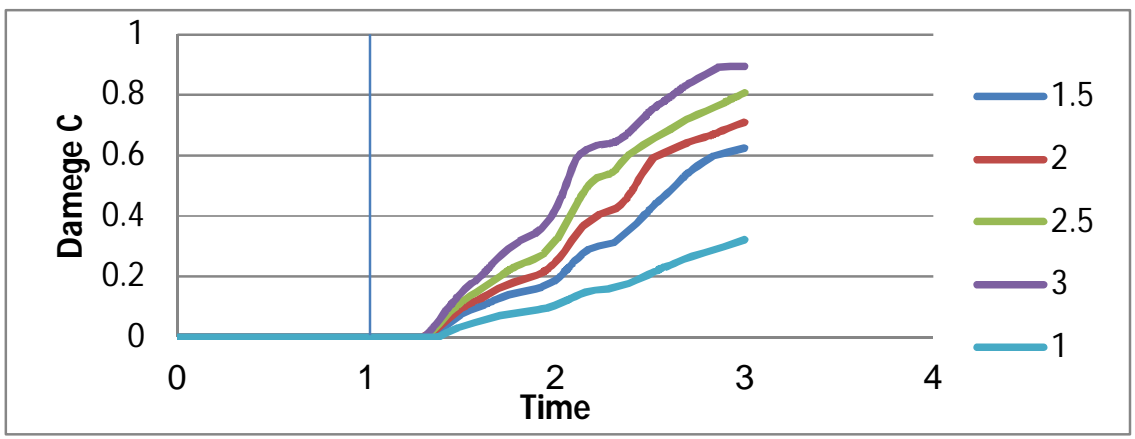

Figure 25. Compression Damage Parameter for Edge Column in Bridge pier with $800 \mathrm{~mm}$ diameter during (1, 1.5, 2, 2.5 and 3) of applied Earthquake Intensity

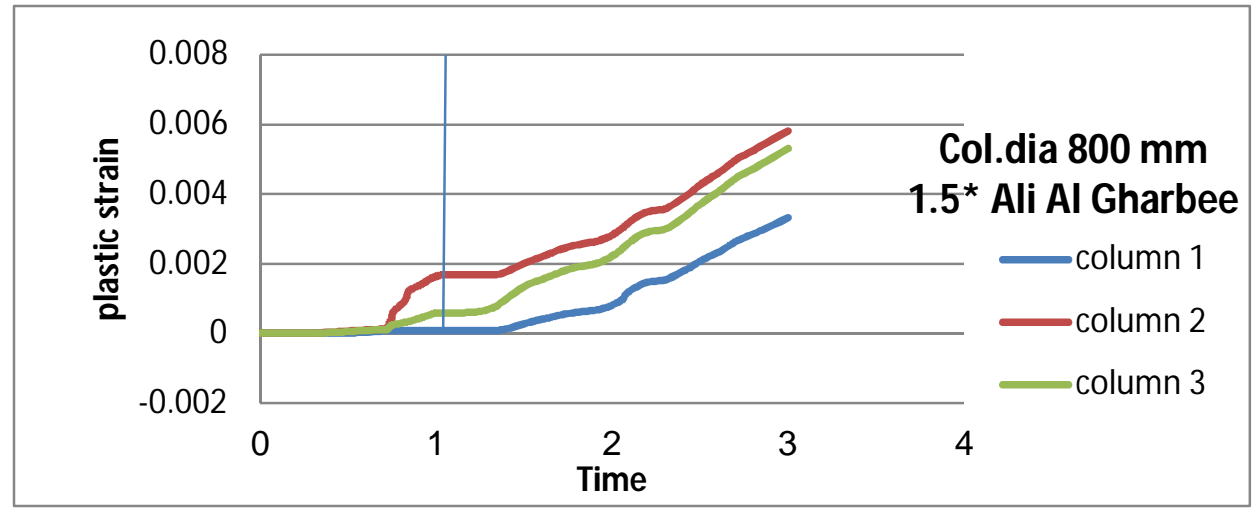

Figure 26. Plastic Strain of Pier with $800 \mathrm{~mm}$ Columns Diameter under 1.5 of Applied Earthquake Intensity

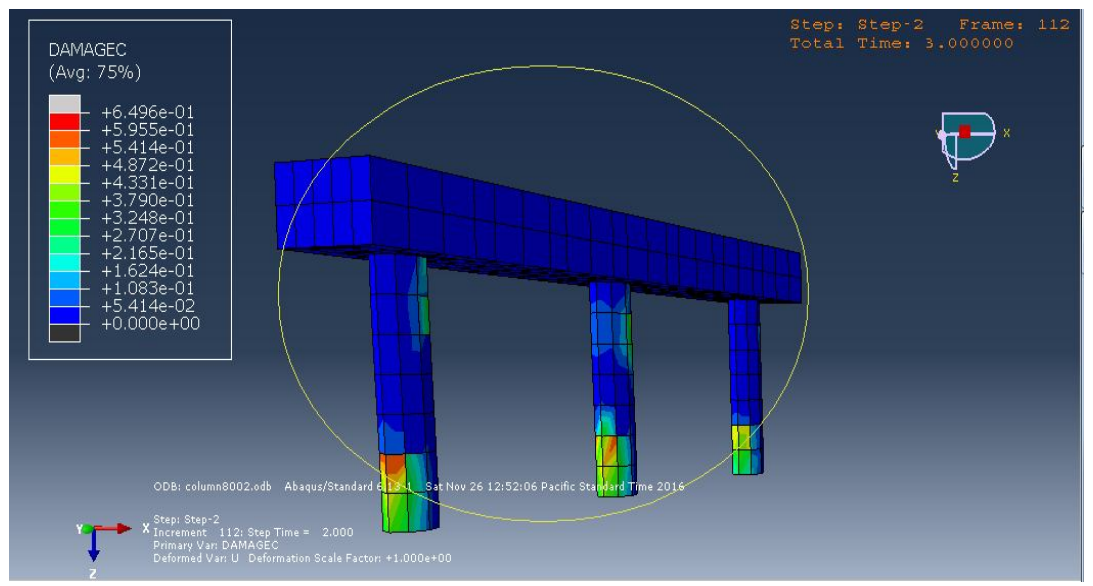

Figure 27. Compression damage location and sequence of Bridge Piers with $800 \mathrm{~mm}$ under 1.5 of Applied Earthquake Intensity 


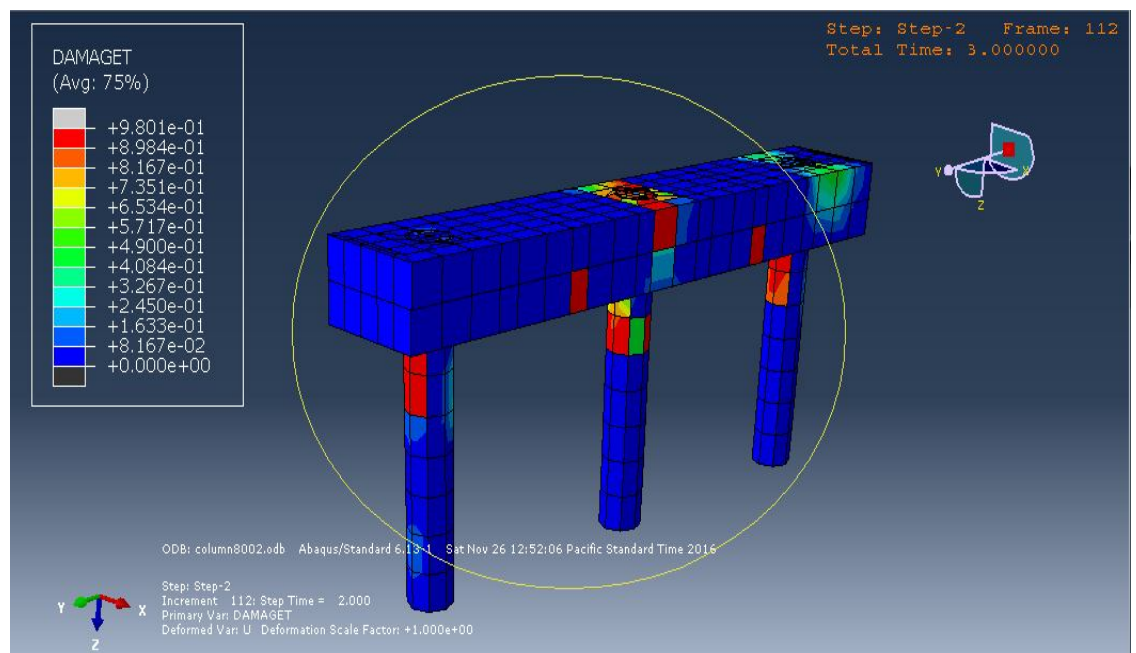

Figure 28. Tension Cracking Location of Bridge Piers with $800 \mathrm{~mm}$ diameter under 1.5 of Applied Earthquake Intensity

Table 7 OverStrength Capacity Ratio for Bridge Pier with $800 \mathrm{~mm}$ diameter columns under different Earthquake Excitation

\begin{tabular}{|l|l|l|l|l|l|}
\hline Column $(800 \mathrm{~mm})$ & $\begin{array}{l}1 * \quad \text { Earthquake } \\
\text { Intensity }\end{array}$ & $\begin{array}{l}1.5 * \text { Earthquake } \\
\text { Intensity }\end{array}$ & $\begin{array}{l}\mathbf{2}^{*} \text { Earthquake } \\
\text { Intensity }\end{array}$ & $\begin{array}{l}2.5 * \text { Earthquake } \\
\text { Intensity }\end{array}$ & $\begin{array}{l}3^{*} \text { Earthquake } \\
\text { Intensity }\end{array}$ \\
\hline $\begin{array}{l}\text { Middle Column } \\
\text { (Column 2) }\end{array}$ & 0.41 & 0.64 & 0.724 & 0.815 & 0.894 \\
\hline $\begin{array}{l}\text { Edge Column } \\
\text { (Column 3) }\end{array}$ & 0.32 & 0.62 & 0.708 & 0.806 & 0.894 \\
\hline
\end{tabular}

\section{Pier with $1200 \mathrm{~mm}$ Diameter Columns}

This pier was subjected to 1, 1.5, 2, 2.5, and 3 multiples of the original Ali Al Gharbee earthquake. Results of the compression damage parameter of the middle column (Column 2) and edge column at far side (Column 3) through the full earthquake duration ( 2 seconds) are shown in Fig. 29 and 30. Plastic strain accumulated with time on the three columns under 2.5 times of earthquake intensity are shown in Fig. 31. Plastic hinges formation with time under 1.5 times of original earthquake excitation is shown in Fig. 32. Tension cracking distribution and locations are shown in Fig. 33 From the full analysis of bridge pier with columns diameter of $1200 \mathrm{~mm}$ each, the over strength capacity ratio of the pier under different earthquake excitations made of multiples of the original Ali Al Gharbee earthquake is given in Table 8. The values show clearly that the pier with $1200 \mathrm{~mm}$ diameter columns can sustain not only the original Ali Al Gharbee earthquake excitation but three times of its magnitude where several plastic hinges will form but the pier will not fail and collapse due to the over strength capacity it has due to its indeterminacy, rigidity and concrete compressive damage capability where it reached a maximum value of one half of its full compression strength at the end of the earthquake excitation. 


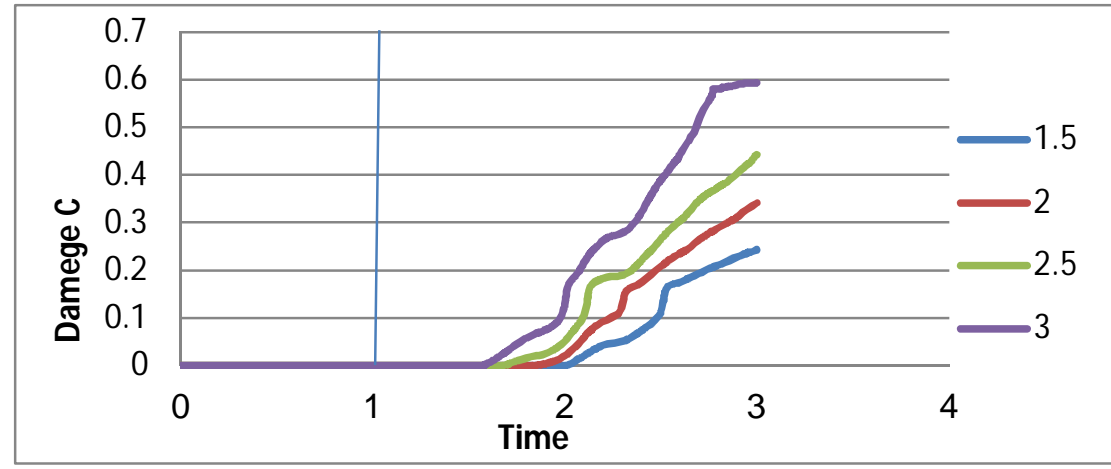

Figure 29. Compression Damage Parameter for Column 2 in Bridge pier with $1200 \mathrm{~mm}$ diameter during ( 1, 1.5, 2 , 2.5 and 3) of applied Earthquake Intensity

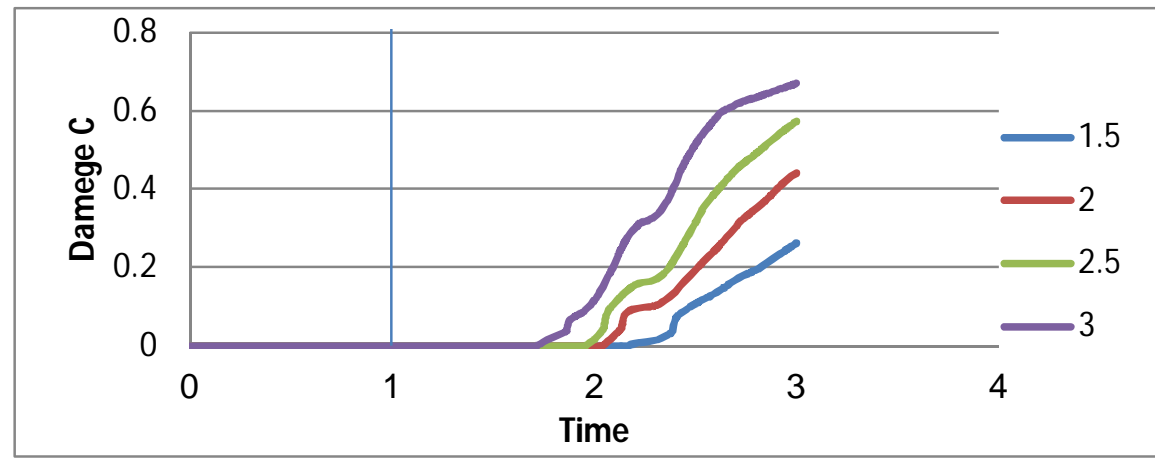

Figure 30. Compression Damage Parameter for Column 3 in Bridge pier with $1200 \mathrm{~mm}$ diameter during (1, 1.5, 2, 2.5 and 3) of applied Earthquake Intensity.

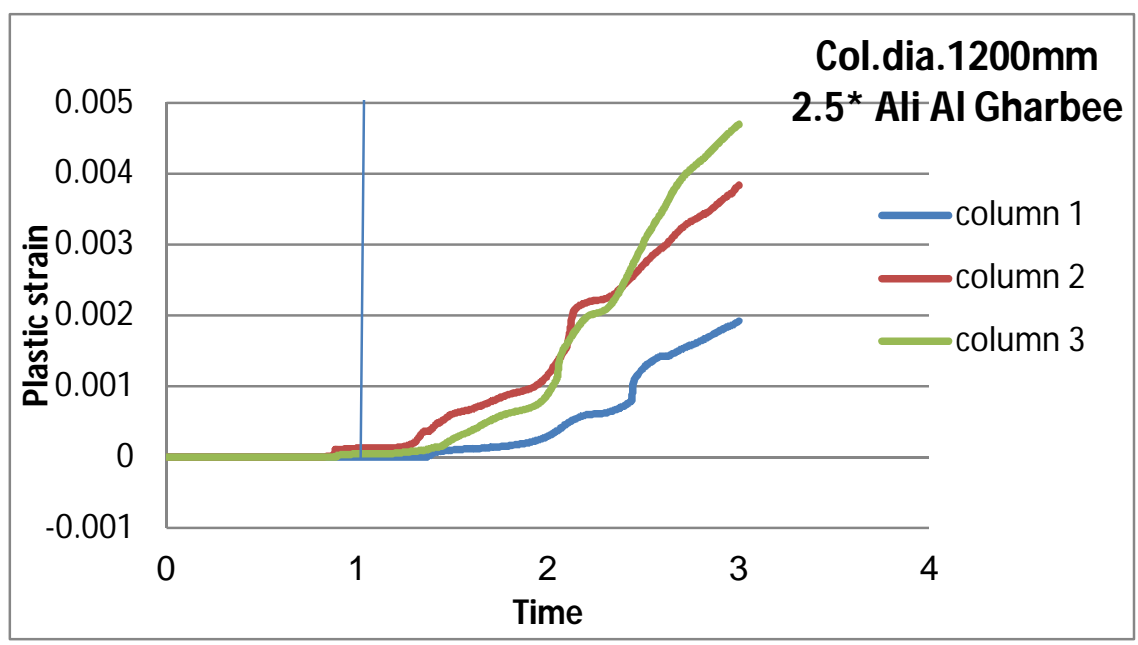

Figure 31. Plastic Strain of Pier with 1200 mm Columns Diameter under 2.5 of Applied Earthquake Intensity 


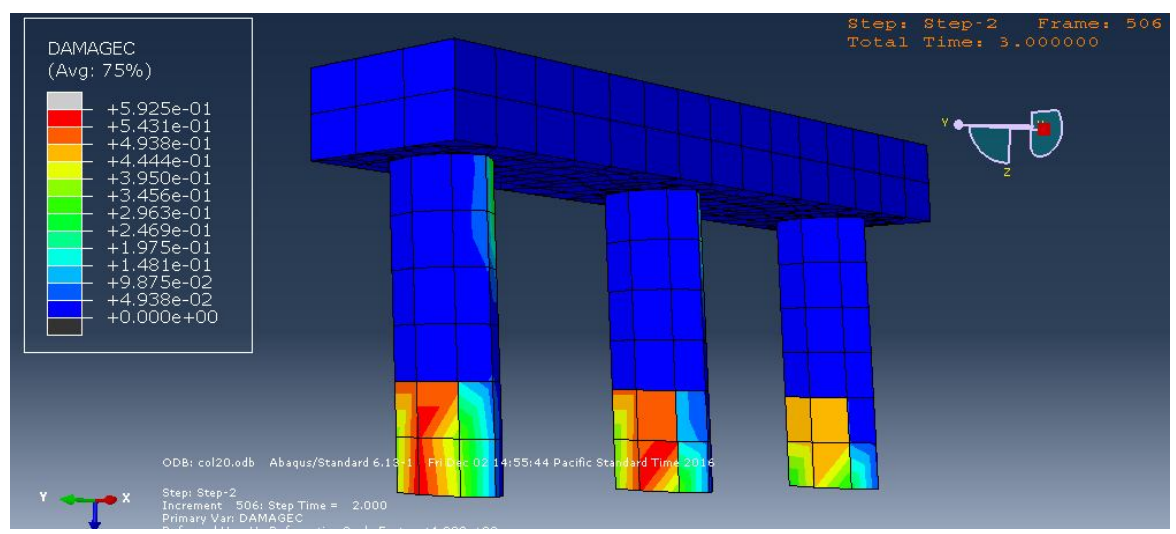

Figure 32. Compression damage location and sequence of Bridge Piers with $1200 \mathrm{~mm}$ under 2.5 of Applied Earthquake Intensity

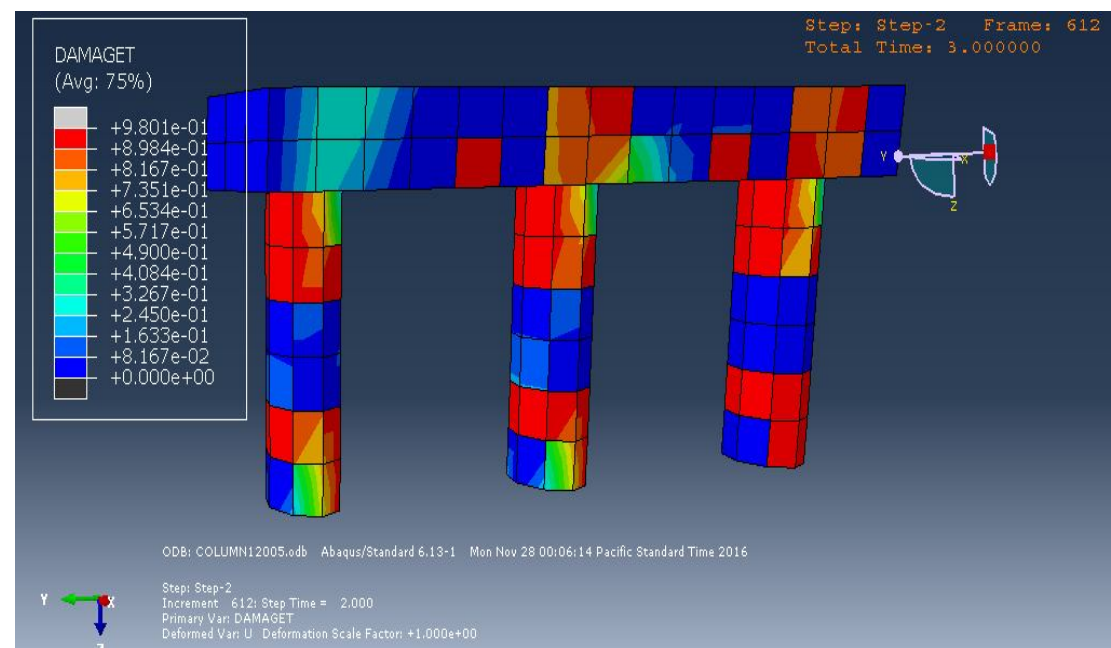

Figure 33. Tension Cracking Location of Bridge Piers with $1200 \mathrm{~mm}$ diameter under 2.5 of Applied Earthquake Intensity

Table 8 Over Strength Capacity Ratio for Bridge Pier with $1200 \mathrm{~mm}$ diameter columns under different Earthquake Excitation

\begin{tabular}{|ll|l|l|l|l|}
\hline Column(1200mm) & $\begin{array}{l}1.5 * \text { Earthquake } \\
\text { Intensity }\end{array}$ & $\begin{array}{l}2^{*} \text { Earthquake } \\
\text { Intensity }\end{array}$ & $\begin{array}{l}2.5 * \text { Earthquake } \\
\text { Intensity }\end{array}$ & $\begin{array}{l}3^{*} \text { Earthquake } \\
\text { Intensity }\end{array}$ \\
\hline $\begin{array}{l}\text { Middle } \\
\text { Column 2) }\end{array}$ & 0.341 & 0.442 & 0.59 \\
\hline $\begin{array}{l}\text { Edge Column } \\
\text { Column 3) }\end{array}$ & $\mathbf{0 . 2 4 3}$ & 0.44 & 0.59 & 0.669 \\
\hline
\end{tabular}

\section{$V$ Conclusions}

From the seismic analyses carried out for different columns diameters of bridge piers and earthquake intensities based on multiples of the original Ali Al Gharbee earthquake, the followings can be concluded:

1. If the original Ali $\mathrm{Al}$ Gharbee earthquake is applied to a bridge pier of $1000 \mathrm{~mm}$ diameter columns, the pier can sustain the earthquake load with maximum compression plastic damage parameter of $17 \%$, and compressive strain of 0.002 at the end of the excitation period while the tensile cracking strain was reached at other locations on the pier but not causing failure by introducing plastic hinges 
leading to a mechanism. The tensile stresses in the main reinforcement reached the yield values at certain locations but didn't affect the overall strength of the pier.

2 Also, if the original Ali Al Gharbee earthquake is applied to a bridge pier of $800 \mathrm{~mm}$ diameter columns, the pier can sustain the earthquake load with maximum compressive plastic damage parameter of $41 \%$, and compressive strain of 0.0036 at the end of the excitation period. It can also sustain two times of the original Ali Al Gharbee earthquake excitation but cannot sustain 2.5 and 3 times of the original one as plastic hinges formed and the structure cannot sustain any additional excitation as displacements were increasing without any additional excitation loads. It is recommended through this work that for typical bridge piers in Iraq columns of $800 \mathrm{~mm}$ in diameter will not be used if earthquake loadings will be considered in the designs of that Bridge.

3 The pier with $1200 \mathrm{~mm}$ diameter columns sustained not only the original Ali Al Gharbee earthquake but its multiples till 3 times of its magnitude where the plastic damage parameter reached $59 \%$ of its full over strength capacity. Such pier can sustain additional compression loads but the tensile cracks were spread in many locations as the concrete has limited strength in tension and the tensile stresses will be handled by the reinforcements. Controlling the reinforcement amount will control the tensile cracks and such piers can go further in over strength capacity.

4 The effect of over strength on the capacity of piers was very clear in the solved problems. Plastic Hinges were formed on different locations but since mechanism was not reached, the pier was able to hold additional loads from the earthquake excitation. Without considering the effect of plastic damage of concrete, such piers were considered fail under the applied earthquake excitation after the formation of first damage zone even if it is not a complete hinge formation.

5 Using and adding the effect of plastic damage parameter in the pier analysis increased the pier capacity in resisting earthquake excitation almost 8 times of the capacity calculated using maximum concrete compressive strength.

6 For zones with earthquake activities, it is recommended not to use columns with diameters of $800 \mathrm{~mm}$ in the reinforced concrete bridge piers generally used in the designs of bridges in Iraq. Columns with diameters of $1000 \mathrm{~mm}$ and larger will be recommended.

\section{REFERENCES}

[1] ABAQUS, (2012), "Abaqus 6.13 Abaqus/CAE User's Manual”, Inc. available at "http://www.maths.cam.ac.uk/computing/software/abaqus docs /docs/v6.12.

[2] Jankowiak, T., \& Lodygowski, T. (2006). Identification of the Parameters of Concrete. Foundations of Civil and Environmental Engineering, 53-69.

[3] Chen, W. F., (2014), "Plasticity in Reinforced Concrete", Fourth Edition, McGraw Hill Book Company.

[4] CEB, (2006), "Reinforced Concrete Frames under Earthquake Loading: State of the Art Report", Comite Euro-International Du Beton.

[5] CEB B242 (2010), “ Ductility of Reinforced Concrete Structures", Comite Euro-International Du Beton. [6] Srinivasan Chandrasekaran, Luciano Nunziante, Giorgio Serino, Federico Carannante, (2014),"Seismic Design Aids for Nonlinear Analysis of Reinforced Concrete Structures", CRC Press. 